\title{
INFLUENCE OF ORGANIZATIONAL CULTURE, LEADERSHIP AND DECISION MAKING ON EMPLOYEE PERFORMANCE AT THE MINISTRY OF DEFENSE OF THE REPUBLIC OF INDONESIA
}

\author{
Nina Ruslinawati ${ }^{1)}$; Syarief Gerald Prasetya ${ }^{2)^{*}}$ \\ Research and Development Agency Researcher of the Ministry of Defense of the Republic of Indonesia; \\ Management Study Program.Universitas Binaniaga Indonesia \\ 1)ninaruslinawaty@yahoo.co.id; ${ }^{21}$ er7et70@gmail.com \\ * Corresponding author
}

Received: October 11, 2020; Accepted: June 28, 2021; Published: June 30, 2021

To cite this article: Ruslinawati,N \& Prasetya,S.G.(2021). Influence of organizational culture, leadership and decision making on employee performance at the Ministry of Defense of the Republic of Indonesia, The Management Journal of BINANIAGA, 6(1), 41-54. doi: 10.33062/mjb.v6i1.385

\begin{abstract}
The research is intended to explain the relationship between employee performance and organizational culture, leadership and decision making. The research used 100 randomly selected samples and analyzed the data using path analysis by inserting all variables into the correlation matrix. The results of the analysis showed decision making was directly influenced by organizational culture and leadership. Then the performance of employees is directly and indirectly influenced by leadership and decision making. But the performance of employees is not directly illuminated by the culture of the organization. Based on the findings explained that variations in employee performance changes can occur due to influenced organizational culture, leadership and decision making. Therefore, the management of employee performance, organizational culture, leadership and decision making should be included in the strategic plan of human resource development at the Ministry of Defense of the Republic of Indonesia. The need to include other variables to estimate employee performance in subsequent research.

Keywords: organizational culture, leadership, decision making, employee performance
\end{abstract}

\section{INTRODUCTION}

Ministry of Defense (Kemhan) as a typical government institution because it is filled by TNI personnel and civil servants who stand in line and as partners are required to increasingly show honest, accountable and professional attitudes, behaviors and performance in carrying out their duties and functions in helping the government in the field of state defense. Defense issues are complex issues and sensitive to government policy. Therefore, the defense issue based on Law No. 32 of 2004 is one of the sectors handled by the central government. To organize the defense of the Minister of Defense of the Republic of Indonesia issued a policy in the form of a Ministerial Regulation with the number: PER/01/M/VIII/2005 concerning the Organization structure and Working Procedure of the Ministry of Defense, it is expected that with the regulation the Ministry of Defense can achieve effective and efficient performance (Jaringan Dokumentasi dan Informasi Hukum Nasional, 2008).

Nina Ruslinawati and Syarief Gerald Prasetya. Influence of organizational culture, leadership and decision making on employee performance at the Ministry of Defense of the Republic of Indonesia 
Good human resources development is believed to be able to maintain the quality of employee productivity, the role of leadership in improving performance contributes to the ability of employees to be able to do a better job. The willingness to work well will not entirely depend on leadership, organizational culture plays an important role in shaping the character of employees. Organizational culture is the basic value of the organization that becomes the basis on which employees carry out their activities and make decisions on behalf of the organization. The culture of the organization can be explicitly stated through organizational documents, communicated openly and discussed with employees and can also be implicitly stated as a fundamental value in decision making and views on acceptable employee behavior (Kotter and Heskett, 2002).

Research conducted by Anco (2017) found that organizational culture has a significant influence on decision making. Then research conducted Layonardo and Adiwijaya (2016) found that leadership style and organizational culture affect employee performance. Similarly, research conducted by Wahyuni (2016) which found that leadership style and organizational culture have an influence on employee performance. In his research, Sudaryana (2015) found that organizational culture has a direct effect on the decision making and commitment of the organization. In addition, leadership also has a direct effect with decision making and organizational commitment and decision making has a direct effect on organizational commitment.

The fundamental difference between this research and previous research is, this research uses path analysis to determine the direct or indirect influence so that the research variables consist of exogenous, endogenous and intervening variables. Therefore, the purpose of research is to know the influence of organizational culture and leadership on decision making and the influence of organizational culture, leadership and decision making on employee performance, either directly or indirectly.

\section{REVIEW OF LITERATURE}

a. Organizational Culture

Culture is a complex totality that includes knowledge, beliefs, art, morals, laws, habits, and every possible ability and habit that people need as members of society. Organizational culture can be said to be the dominant values espoused by the organization, as a philosophy that guides the wisdom of the organization towards employees and customers, as a way of work done in that place and the basic assumptions and beliefs that exist among members of the organization (Brown, 1998).

Culture creates norms that have the power to sharpen the behavior of individuals in organizational groups. Organizational culture can be the energy or strength of employees to carry out the task of achieving work performance. Organizational culture can be a persistent and patterned way of working in the organization, culture as well as a moral element in the organization and a moral factor in leadership (Schein, 1991).

Organizational culture can be a shared set of values that is a tool of supervising organization members in interacting with suppliers, customers and people outside the organization. Organizational culture can be used to achieve the competitive advantage and effectiveness of the organization through its cultural influence on the members of the organization (Schein, 1991). Mullins (2005) says organizations are effective if done correctly and the results relate to specific goals, objects or tasks.

Shared vision is nothing but an organizational culture is very important in an organization, because the shared vision encourages members of the organization willing to sacrifice to achieve common goals in the organization. A shared vision is a vision that is truly shared, not an individual vision of a leader. This means that what a leader sees is also seen by members of the organization. The same vision will result in mutual

Nina Ruslinawati and Syarief Gerald Prasetya. Influence of organizational culture, leadership and decision making on employee performance at the Ministry of Defense of the Republic of 
commitment. Leaders and members of the organization have a shared commitment to the same image that will be achieved in the future (Mullins, 2005).

Brown (1998) mentions at least five cultural functions of the organization, namely reducing internal conflict, coordination and supervision, reducing uncertainty, motivation and encouraging competitive advantage. The first function of organizational culture according to Brown is to minimize conflict. The second function carries out coordination and supervision. Coordination is related to equalizing actions in a timely manner between different parts. The third function reduces uncertainty, the organization is a part of society in general that always faces uncertainty and complexity. The fourth function provides motivation to the members of the organization and the fifth function encourages the achievement of competitive advantage.

Organizational culture can also be said as a form of belief, value, a way that can be learned to overcome and live in the organization, the culture of the organization tends to be realized by members of the organization. Robbins (2002) explained that the culture of the organization is a value system held and carried out by members of the organization, so that such a thing can distinguish the organization from other organizations. The value system is built by seven characteristics as essence of organizational culture, namely Innovation and Risk Taking, Attention to Detail, Outcome Orientation, People Orientation, Team Orientation, and Aggressiveness, Stability,

\section{b. Leadership}

Dubrin (2005) suggests that leadership is an attempt to influence many people through communication to achieve the goal of command, an action that causes others to act and respond and lead to positive change. In addition, leadership can be interpreted as an important dynamic force that motivates and coordinates the organization in achieving goals or the ability to create confidence and support among subordinates so that organizational goals can be achieved.

Siagian (2002) suggests that leadership is one's ability to influence others (his subordinates) in such a way that the other person is willing to do the will of the leader even though he or she may not personally like it. Robbins (2002) said leadership is the ability to influence a group toward achieving goals.

The role of leadership in the organization is three forms, namely interpersonal roles, informational roles and decision-making roles. Mintzberg (in Yasin, 2011) suggests that the leadership role in the organization is as a vision manager, motivator, analyst and mastery of the work. The success of business activities is largely determined by the quality of leadership or management and the commitment of the top leadership of the organization to the necessary energy investments as well as the personal efforts of the leadership.

There are nine leadership roles in the organization, namely leader as planner, leader as policy maker, leader as expert, leader as executor, leader as controller, leader as giver of gifts or punishment, leader as example and signs or symbols, leader as a place to inflict all wrongdoing and in lieu of the role of other members (Tika, 2006).

Davis (1972) based on four main characteristics or traits of leadership, that have influences on the success of organizational leadership, namely intelligence, maturity and breadth of social relationships, self-motivation and encouragement of achievement and attitudes of human relationships. The leader always tries to find a way to be able to create a situation that causes the leadership to raise awareness to carry out what a leader wants. This is key to the development and improvement of the organization in which he works. Leaders are the ones who take full responsibility for the success or not of the organization in realizing a quality and outstanding organization.

Nina Ruslinawati and Syarief Gerald Prasetya. Influence of organizational culture, leadership and decision making on employee performance at the Ministry of Defense of the Republic of Indonesia 


\section{c. Decision Making}

Decision making is a key part of a manager's activities. This activity plays an important role, especially if the manager performs the planning function. Planning concerns the very important and long-term decisions that managers can make. In the planning process, the manager decides the goals of the organization to be achieved, the resources to be used and who will carry out each task as needed. The entire planning process involves the manager in a series of decision-making situations. The quality of the manager's decisions will determine the effectiveness of the plan drawn up (Huber, 1990).

Decision making is described as a process that goes through a series of activities chosen as solving a particular problem. Decision making is distinguished from choice making and from problem solving. Decision making is defined as the process of producing and choosing several alternatives to solve problems. Programmed decisions will become automatic because the knowledge that individuals have, whether male or female allows them to recognize and identify situations and ensure the activities they need (Colquitt and Wesson, 2009).

Every decision that will be taken, whether programmed or not programmed will always be identified by the decision-making party. The identification concerns whether the issue is recognized or not and whether the organization has experienced the problem. Managers make decisions now for the activities to be implemented and the goals to be achieved in the future. These decision-making situations concern various unknown and difficult aspects, such as competitor reactions, inflation rates, economic conditions and so on. The level of uncertainty in various situations will vary, therefore the manager will face three kinds of situations, namely certainty, risk and uncertainty.

Gibson (2004) stated that there are currently three ways of making decisions taken by executives. These three methods are called strategic decision-making process types, namely Sporadic Process, Fluid Process and Constricted Process. Managers will find it difficult to make decisions without involving their subordinates. This engagement can be formal, such as the group's use in decision-making or informal ways such as asking for ideas. The help of subordinates can occur at any stage of the decision-making process. Many managers consider that decisions taken in groups will be more effective because they maximize other knowledge. But some other managers avoid group involvement, considering it slow and impractical and often resulting in weightless decisions.

\section{d. Performance}

Performance can be said to be the result or overall success rate of a person during a certain period in carrying out a task compared to various possibilities, such as the standard of work, targets or targets or criteria that have been pre-established and have been agreed together (Colquitt and Wesson, 2009).

Performance is a goal determined in the process of formulating goals and possible results. If the existing strategy is continued to produce maximum results, attention is needed to several indicators that allow to generate performance, among others, the sense of togetherness then the spirit of work will increase and automatically improve work performance. To avoid poor performance it is necessary to pay attention to the factors that allow blocking good performance i.e. insufficient training, incompetence, weak disciplinary, low standards, poor management and personal problems (Stoner, 1996).

The performance and commitment of the organization is influenced by a variety of factors. One of the factors that affect employee performance is decision making. If the decision-making process goes well, then it is expected that the decision making is also appropriate and effective. In the decision-making process will be influenced by several factors, including organizational culture and leadership. The culture of the organization is

Nina Ruslinawati and Syarief Gerald Prasetya. Influence of organizational culture, leadership and decision making on employee performance at the Ministry of Defense of the Republic of 
included in it about the values, behaviors and rules that are considered correct and appropriate according to all personnel in it, while leadership will concern how a leader's style in supervising and coordinating his subordinates (Colquitt and Wesson, 2009).

Employee performance is the level of work productivity of employees in achieving job requirements. Employee performance is the result that an employee has achieved in a certain period of time. To see whether or not personnel performance improves, the factors that become indicators are creativity (ideas or ideas), analytical skills and choosing alternatives, Learning Process and Problem Solving (Simamora, 2005).

Colquitt and Wesson (2009) stated that the concept of performance is defined as the value of a set of employee behaviors that contribute, both positively and negatively to the fulfillment of organizational goals. Performance is determined by three factors, namely task performance, citizenship behavior and counter productive behavior.

Employee performance achievement can be influenced by ability and motivation factors. This can be formulated in several factors, namely the ability of employees and motivation factors formed from the attitude of an employee in dealing with a work situation (Davis, 1972).

e. Research Hypotheses

Research hypotheses include:

- Organizational culture directly affects decision making

- Leadership directly affects decision making

- Organizational culture directly affects employee performance

- Leadership directly affects employee performance

- Decision making directly affects employee performance

\section{RESEARCH METHOD}

a. Target and Time of Research

The target of this Research is Civil Servants in the Ministry of Defense.The implementation time of this study is for one year in 2020 .

b. Research Method

The research method used in this research is causal analysis.

c. Sampling

Sampling in this research used simple random sampling. The research sample was taken by 100 respondents with the assumption of homogeneous samples.

\section{d. Data Collection Techniques}

To collect research data is conducted using questionnaires. According to SG Prasetya and Y Wadhani (2018) by giving a closed question that has been provided the answer. So that, the respondent lives one of the answers that corresponds to his assessment.

e. Data Source and Type

This study uses primary data obtained directly from the respondents.

Nina Ruslinawati and Syarief Gerald Prasetya. Influence of organizational culture, leadership and decision making on employee performance at the Ministry of Defense of the Republic of Indonesia 


\section{f. Data Analysis Techniques}

Data analysis methods or techniques used in this research include:

1) Initial data analysis was conducted validity and reliability tests aimed at testing the accuracy of questionnaires used to measure research variables.

2) Data analysis is done by path analysis. Stages in the analysis of this path include (Ghozali, 2005):

- Descriptive analysis aims to describe the data of each variable.

- Test the requirements of analysis, which consists of normality test, simple regression significance and linearity test with ANOVA, calculation of correlation coefficient matrix and testing as well as calculation of phi coefficient (path).

- Hypothesis test using t-test, statistical hypothesis used:

$>\quad \mathrm{Ho}_{3} \beta_{31} \leq 0$, organizational culture has no direct effect on decision making making

Ha: $\beta_{31}>0$, organizational culture has direct effect on decision

$>\quad \mathrm{Ho}: \beta_{32} \leq 0$, leadership has no direct effect on decision making

Ha: $\beta_{32}>0$, leadership has direct effect on decision making

Ho: $\beta_{41} \leq 0$, organizational culture has no direct effect on employee performance

Ha: $\beta_{41}>0$, organizational culture has direct effect on employee performance

Ho: $\beta_{42} \leq 0$, leadership has no direct effect on employee performance

$\mathrm{Ha}: \beta_{42}>0$, leadership has direct effect on employee

Ho: $\beta_{43} \leq 0$, decision making has no direct effect on employee performance

Ha: $\beta_{43}>0$, decision making has direct effect on employee performance

Testing criteria:

- If value of $t$-count $\leq t_{\text {table }}$ or Sig. $\geq 0,05$ then Ho accepted

- If value of $t$-count $>t$ table or Sig. $\leq 0,05$ then $\mathrm{Ho}$ is rejected

\section{RESULT AND DISCUSSION}

a. Description of the results of the research

Research variables consist of organizational culture $(X 1)$, leadership $(X 2)$, decision making (X3) and performance (X4). The result of the data description of the variable is as follows:

Table 1. Summary of Descriptive Data

\begin{tabular}{lrrrr}
\hline & \multicolumn{4}{c}{ Variables } \\
\cline { 2 - 5 } & \multicolumn{1}{c}{$\mathbf{X}_{\mathbf{4}}$} & \multicolumn{1}{c}{$\mathbf{X}_{\mathbf{1}}$} & \multicolumn{1}{c}{$\mathbf{X}_{\mathbf{2}}$} & \multicolumn{1}{c}{$\mathbf{X}_{\mathbf{3}}$} \\
\hline Respondent & 100 & 100 & 100 & 100 \\
\hline Question Items & 32 & 17 & 13 & 12 \\
\hline Mean & 78.05 & 45.27 & 39.37 & 29.85 \\
\hline Median & 77.50 & 44.00 & 40.00 & 29.50 \\
\hline Modus & 73.00 & 44.00 & 42.00 & 27.00 \\
\hline Standard Deviation & 9.065 & 6.053 & 3.984 & 4.696 \\
\hline Variant & 82.169 & 36.644 & 15.872 & 22.048 \\
\hline Range & 47 & 21 & 19 & 22 \\
\hline Minimum & 60 & 35 & 29 & 19 \\
\hline Maximum & 107 & 56 & 48 & 41 \\
\hline Total & 7,805 & 4,527 & 3,937 & 2,985 \\
\hline
\end{tabular}

Nina Ruslinawati and Syarief Gerald Prasetya. Influence of organizational culture, leadership and decision making on employee performance at the Ministry of Defense of the Republic of Indonesia 
b. Testing of analysis requirements

Testing of analysis requirements consists of normality test with One Sample Kolmogorov Smirnov test with significance level of 0.05 obtained atable value in the sample as much as 100 is 0.136 obtained as follows:

Table 2. Summary of Normality Test Results

\begin{tabular}{ccccc}
\hline Variables & a absolute & $\begin{array}{c}\mathbf{a}_{\text {table } \alpha} \\
0,05\end{array}$ & $\begin{array}{c}\text { Asymp Value. Sig } \\
(2 \text {-tailed)/ } \\
\text { significant value }\end{array}$ & Remarks \\
\hline $\mathrm{X}_{4}$ & 0.092 & 0.136 & 0.359 & Normal \\
\hline $\mathrm{X}_{1}$ & 0.108 & 0.136 & 0.193 & Normal \\
\hline $\mathrm{X}_{2}$ & 0.085 & 0.136 & 0.459 & Normal \\
\hline $\mathrm{X}_{3}$ & 0.077 & 0.136 & 0.589 & Normal \\
\hline
\end{tabular}

Then the results of linearity and significance of regression and correlation test are described as follows:

Table 3. Summary of Regression Test, Linearity Test and Correlation Analysis

\begin{tabular}{lccccccc}
\hline \multirow{2}{*}{ Causal } & \multicolumn{2}{c}{ Regression } & \multicolumn{3}{c}{ Linearity } & Correlation & \multicolumn{2}{c}{ Correlation } \\
\cline { 2 - 7 } & $\mathbf{F}_{\text {count }}$ & $\boldsymbol{F}_{\text {table }}$ & $\boldsymbol{F}_{\text {count }} \boldsymbol{F}_{\text {table }}$ & Coefficient & $\mathbf{t}_{\text {count }}$ & $\mathbf{t}_{\text {table }}$ \\
\hline $\mathrm{X}_{3}$ on $\mathrm{X}_{1}$ & 36.64 & 3.94 & 1.65 & 1.71 & 0.52 & 6.05 & 1.66 \\
\hline $\mathrm{X}_{3}$ on $\mathrm{X}_{2}$ & 26.74 & 3.94 & 1.15 & 1.75 & 0.46 & 5.17 & 1.66 \\
\hline $\mathrm{X}_{4}$ on $\mathrm{X}_{1}$ & 16.56 & 3.94 & 0.93 & 1.71 & 0.38 & 4.07 & 1.66 \\
\hline $\mathrm{X}_{4}$ on $\mathrm{X}_{2}$ & 24.01 & 3.94 & 0.69 & 1.75 & 0.44 & 4.90 & 1.66 \\
\hline $\mathrm{X}_{4}$ on $\mathrm{X}_{3}$ & 28.34 & 3.94 & 0.78 & 1.73 & 0.47 & 5.32 & 1.66 \\
\hline
\end{tabular}

c. Model Testing

The calculation of the path coefficient value is based on the correlation value between variables. The absence of path coefficient is based on research models. If there is a path, it is calculated the coefficient value, but if there is no path then the coefficient is not calculated. From the research model made, there are only 4 paths, namely:

Table 4. Value of Path Coefficient of Effect Between Variables

\begin{tabular}{lcl}
\hline \multicolumn{1}{c}{ Causal } & $\begin{array}{c}\text { Correlation } \\
\text { Coefficient }\end{array}$ & $\begin{array}{c}\text { Path } \\
\text { Coefficient }\end{array}$ \\
\hline $\mathrm{X}_{3}$ on $\mathrm{X}_{1}$ & 0.522 & 0.322 \\
\hline $\mathrm{X}_{3}$ on $\mathrm{X}_{2}$ & 0.463 & 0.386 \\
\hline $\mathrm{X}_{4}$ on $\mathrm{X}_{1}$ & 0.380 & Not Availlable \\
\hline $\mathrm{X}_{4}$ on $\mathrm{X}_{2}$ & 0.444 & 0.432 \\
\hline $\mathrm{X}_{4}$ on $\mathrm{X}_{3}$ & 0.474 & 0.359 \\
\hline
\end{tabular}

The results of this calculation are described as follows:

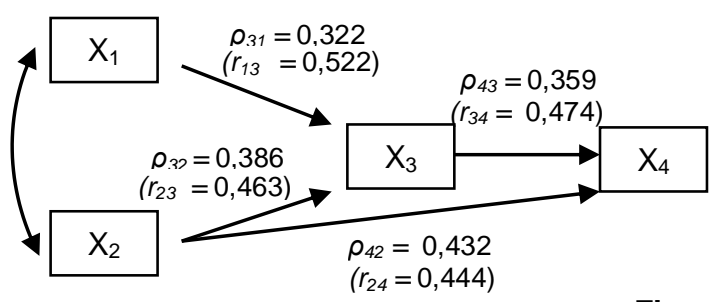

Figure 1.

Value of Correlation Coefficient and Path Coefficient of Modified Research Model

Nina Ruslinawati and Syarief Gerald Prasetya. Influence of organizational culture, leadership and decision making on employee performance at the Ministry of Defense of the Republic of Indonesia 


\section{d. Hypothesis Testing}

Hypothesis testing uses $t$-test by comparing $t_{\text {count }}$ values with $t_{\text {table }}$ values. The $t_{\text {table }}$ value in this research used a significance level of 0.05 with a sample of 100 obtained of 1,661 for a significance level of 0.01 of 2,365 .

- The direct influence of organizational culture on decision making

Hypothesis testing is:

$$
\begin{aligned}
& \mathrm{H}_{0}: \beta_{31} \leq 0 \\
& \mathrm{H}_{1}: \beta_{31}>0
\end{aligned}
$$

The result of calculating the path value obtained coefficient of line $\rho 31=0.322$ with a $t_{\text {count }}$ value of 4,853 greater than the value of 0.05 table of 1,661 and 0.01 table of 2.365 $(4,853>1,661$ and $4,853>2,365)$, thus $\mathrm{H} 0$ was rejected and $\mathrm{H} 1$ accepted which means that the organizational culture (X1) has a positive direct effect on decision making (X3).

- The direct influence of leadership on decision making

Hypothesis testing is:

$\mathrm{H}_{0}: \beta_{32} \leq 0$

$\mathrm{H}_{1}: \beta_{32}>0$

The calculation result of path value obtained coefficient of line $\rho 32=0.386$ with tcount value of 3,833 greater than the value of 0.05 table of 1,661 and 0.01 table of 2.01365 $(3,833>1,661$ and $3,833>2,365)$, thus $\mathrm{H} 0$ was rejected and $\mathrm{H} 1$ accepted which means that leadership (X2) has a positive direct effect on decision making (X3).

- The direct influence of organizational culture on performance

Hypothesis testing is:

$\mathrm{H}_{0}: \beta_{41} \leq 0$

$\mathrm{H}_{1}: \beta_{41}>0$

The calculation result of the path value obtained coefficient of line $\rho 41=0.151$ with a tcount value of 1,515 smaller than the value of 0.05 table of 1,661 and 0.01 table of 2.01 $365(1,515<1,661$ and $1,515<2,365)$, thus $\mathrm{H} 0$ was accepted and $\mathrm{H} 1$ rejected which meant that the organizational culture (X1) had no direct effect on performance (X4). But the culture of the organization had an indirect effect on performance through decision-making of 0.116 .

- The direct influence of leadership on performance Hypothesis testing is:

$$
\begin{aligned}
& \mathrm{H}_{0}: \beta_{42} \leq 0 \\
& \mathrm{H}_{1}: \beta_{42}>0
\end{aligned}
$$

The result of calculating the path value is obtained coefficient of path $\rho 42=0.432$ with a tcount value of 2, 955 greater than the 0.05 trable value of 1,661 and the 0.01 table of 2,365 (2,955 > 1,661 and 2,955 > 2,365), thus $\mathrm{H} 0$ was rejected and $\mathrm{H} 1$ was accepted which means that leadership (X2) directly affects performance (X4). In addition, leadership had an indirect effect on performance through decision making of 0.139 .

- The direct influence of decision making on performance

Hypothesis testing is:

$\mathrm{H}_{0}: \beta_{43} \leq 0$

$\mathrm{H}_{1}: \beta_{43}>0$

Based on the calculation of the path value obtained coefficient of line $\rho 43=0.359$ with a tcount value of 3,533 greater than the value of 0.05 table of 1.661 and 0.01 table of 2.01 365 (3.533 > 1.661 and $3.533>2.365$ ), thus $\mathrm{H} 0$ was rejected and $\mathrm{H} 1$ accepted which means that decision making (X3) directly affects performance (X4)

Nina Ruslinawati and Syarief Gerald Prasetya. Influence of organizational culture, leadership and decision making on employee performance at the Ministry of Defense of the Republic of 
e. Calculation of coefficients of direct and indirect influence pathways

The path coefficient value is used to determine the path value between variables either directly or indirectly. The calculation result of the direct and indirect influence path coefficient value is described as follows:

Table 5.Summary of Coefficient Values of Direct and Indirect Influence Paths Between

\begin{tabular}{|c|c|c|c|}
\hline \multirow{3}{*}{ Variables } & \multicolumn{2}{|c|}{ Variables } & \multirow{3}{*}{ Total } \\
\hline & Cause & uence & \\
\hline & Direct & Indirect & \\
\hline $\begin{array}{l}\text { Organizational } \\
\text { Culture on Decision } \\
\text { Making } \\
\left(X_{1} \text { on } X_{3}\right)\end{array}$ & 0.322 & - & 0.322 \\
\hline $\begin{array}{l}\text { Leadership on } \\
\text { Decision Making } \\
\left(X_{2} \text { on } X_{3}\right)\end{array}$ & 0.386 & - & 0.386 \\
\hline $\begin{array}{l}\text { Organizational } \\
\text { Culture on } \\
\text { Performance } \\
\left(\mathrm{X}_{1} \text { on } \mathrm{X}_{4}\right)\end{array}$ & - & 0.116 & 0.116 \\
\hline $\begin{array}{l}\text { Leadership on } \\
\text { Performance } \\
\left(X_{2} \text { on } X_{4}\right)\end{array}$ & 0.432 & 0.139 & 0.571 \\
\hline $\begin{array}{l}\text { Decision Making on } \\
\text { Performance } \\
\left(X_{3} \text { on } X_{4}\right)\end{array}$ & 0.359 & - & 0.359 \\
\hline
\end{tabular}

f. Discussion

- Organizational Culture and Decision Making

The relationship and cultural influence of the organization on decision making is positive, with a large 0.522 relationship. The lack of organizational culture is seen from the attitude of employees who are still indifferent to the tasks given, the low level of employee discipline characterized by the increasing number of employees who do not enter work for no reason. This causes decisions to be taken sometimes not in accordance with the objectives to be achieved. In addition, because of this indifferent attitude, employees are reluctant and do not even want to involve themselves in decision making. This can happen because the Ministry of Defense does not involve employees in decision making. Therefore, it is natural for employees to think that the decisions taken tend to be unilateral (impartial to employees).

- Leadership and Decision Making

The relationship and influence of leadership on decision-making is positive with a large relationship of 0.463 . It cannot be said that the leadership in the Ministry of Defense is good because the policies taken by the leadership often change. In addition, this can be seen from the attitude of leaders who tend to be authoritarian. This condition causes the decision-making to be less good because the decision taken does not involve employees.

\section{- Organizational Culture and Performance}

The relationship and cultural influence of the organization with the performance is positive with a large relationship of 0.380 . The poor performance of employees is reflected by the lack of employees completing the work given and also the low level of employee discipline. But through changes in the decision-making process in a better

Nina Ruslinawati and Syarief Gerald Prasetya. Influence of organizational culture, leadership and decision making on employee performance at the Ministry of Defense of the Republic of Indonesia 
direction, organizational culture indirectly affects employee performance. Organizational culture will be able to produce positive behavior if followed by efforts to reward employees as part of the organization, by providing opportunities for employees to provide input for the progress of the organization.

\section{- Leadership and Performance}

The relationship and influence of leadership on performance was positive with a large 0.444 relationship. This poor leadership attitude can be seen from the responses of employees who mostly give hesitant and dis-agree responses to leadership variables. This poor leadership, causes employee performance is also less good. Qualified leaders are leaders who can be democratic and open in decision making. In this case the leadership will try to include employees (both through delegates) in decision making. It can therefore be said that the decisions taken are based on mutual decisions.

\section{- Decision Making and Performance}

The relationship and influence of decision-making on performance was positive with a large 0.474 relationship. Decision making is said to be good if in the process is done jointly so that obtaining will have more alternative decisions. The involvement of employees in the decision-making process will affect the morale of employees. This can happen because with a process like this, employees will feel valued and recognized by the organization that they are part of the organization. In contrast to the process conducted individually or in certain groups, employees will feel ostracized and even feel that they are not part of the organization.

\section{g. Research limitations}

- Research data taken only from a few employees who could be employees do not answer honestly (objectively) and there is a possibility that employees lack the knowledge to answer it.

- The variables researched were limited to three variables that affected performance.

- The research did not discuss and examine the influence of leadership on organizational culture.

\section{CONCLUSIONS AND RECOMMENDATIONS}

a. Conclusions

Based on the results of the analysis and discussion that has been described, then this research can be concluded as follows:

- Organizational culture has a positive direct influence on decision making.

- Leadership has a positive direct influence on decision making.

- Organizational culture has a positive direct influence on employee performance. In this study it was not proven to significantly direct influence the culture of the organization on performance But it is known that organizational culture indirectly positively affects performance through decision making.

- Leadership has a positive direct influence on performance. It was also obtained that leadership had an indirect positive influence on performance through decision making.

- Decision making has a positive direct influence on performance.

b. Implications

The implications of the results of the research include:

Nina Ruslinawati and Syarief Gerald Prasetya. Influence of organizational culture, leadership and decision making on employee performance at the Ministry of Defense of the Republic of Indonesia 
- Implications for Policy

It is necessary to improve the cultural condition of the organization in a better direction. Improvement of organizational culture can be done by improving employees' understanding of the importance of organizational culture. Then it is necessary for the leadership to be democratic in decision making.

- Theoretical Implication

Based on these findings, only the direct influence of organizational culture on performance is incompatible with theories, so theoretical development as an implication of these research results only leads to leadership, decision making and its influence on direct or indirect performance.

- Research Implication

Based on these findings can be attempted to improve and accomplish subsequent studies by considering other variables that may have a stronger influence than the results of this study.

\section{c. Recommendations}

Some of the suggestions that researchers can give include:

- The Ministry of Defense needs to make continuous improvements and socialization on the principles of organizational culture to employees in accordance with the vision and mission of the organization.

- Conducting an ongoing evaluation of the conformity of organizational culture embraced by civil servants and the military in the body of the Ministry of Defense.

\section{REFERENCE}

Anco. (2017). Budaya Organisasi dan Pengambilan Keputusan. Universitas Muhammadiyah Prof. Dr. Hamka. Shautut tarbiyah edisi Ke-36 Tahun XXII, Mei 2017.

Brown, A. (1998). Organizational Culture. Singapura : Prentice Hall.

Colquitt, L.P. \& Wesson,W. (2009). Organizational Behavior : Improving Performance and Commitment in the Workplace. Singapura : McGraw Hill International Edition.

Davis, K. (1972). Human Behavior at Work, Fourth Edition. New York : McGraw Hill Company.

Dubrin, A.J. (2005). Leadership. (Terjemahan) Edisi Kedua. Jakarta : Prenada Media.

Ghozali, I \& Fuad. 2005. Structural Equation Modeling. Semarang : Badan Penerbitan Universitas Diponegoro.

Gibson, Ivancevich Donnely Konopaske. (2004). Organizations, Behavior, Structure, Processes, $8^{\text {th }}$ Edition. Singapore : Mc Graw-Hill.

Hasibuan, M.S.P. (2000). Manajemen Sumber Daya Manusia, Edisi Revisi. Jogjakarta : BPFE.

Huber, G.P. (1990). Managerial Decision Making. Glenoiew : Scoot Foresman.

Jaringan Dokumentasi dan Informasi Hukum Nasional. (2008). Peraturan Perundangundangan Tingkat Pusat. https://jdihn.go.id/search/pusat/detail/675663

Nina Ruslinawati and Syarief Gerald Prasetya. Influence of organizational culture, leadership and decision making on employee performance at the Ministry of Defense of the Republic of Indonesia 
The Management Journal of BINANIAGA Vol. 06, No. 01, June 2021

p-ISSN: 2527 - 4317, e-ISSN: $2580-149 x$

$6^{\text {th }}$ Accreditation Rating: April 04, $2019-$ April 03, 2024

Kotter, J.P \& Heskett, J.L. (1992). Corporate Culture and Performance. New York : The Free Press.

Layonardo, I.S \& Adiwijaya, M. (2016). Pengaruh Gaya Kepemimpinan dan Budaya Organisasi Terhadap Kinerja Karyawan CV.X. Program Manajemen Bisnis Program Studi Manajemen Universitas Kristen Petra, Surabaya. AGORA, 4 (2).

Luthans, F. (2002). Organizational Behavior, Ninth Edition. Singapura : McGraw Hill International Editions.

Mullins, L.J. (2005). Management and Organizational Behavior. Spain : Mateu-Cromo Artes Graficas

Prasetya, S. G. (2019). Analisis Balance Score Card Sebagai Suatu Alat Pengukuran Kinerja Perusahaan (Studi Kasus pada PT. Sierad Produce Tbk.). Jurnal IImiah Binaniaga. https://doi.org/10.33062 /jib.v7i01.278

Prasetya, S. G., \& Wardhani, Y. (2017). An Analysis Regarding The Effects Of The Employees And Working Process Upon The Level Of Customer Satisfaction At Pt Telkom Tbk Bogor. The Management Journal of Binaniaga. https://doi.org /10.33062/mjb.v2i02.135

Prasetya, S. G., \& Wardhani, Y. (2018). The Influence Of Budgeting Participation And Asymmetric Information Against The Budgeting Variants Refers To The Organization Commitment As The Intervening Variable Of The Survey At Food And Beverage Company In The Industrial Area Jababeka Karawang. The Accounting Journal of Binaniaga. https://doi.org/10.33062/ajb.v1i1.90

Prasetya, S. G., \& Wardhani, Y. (2019). Analisis Dampak Ekonomi Pedagang Kaki Lima Di Kota Bogor Dengan Pendekatan Input Output Analysis. Jurnal Manajemen Pembangunan Daerah. https://doi.org/10.29244/jurnal_mpd.v10i2.27790

Robbins, J. (2002). Organizational Behavior, 13 ${ }^{\text {th }}$ Editon. New Jersey : Pearson International Edition.

Schein, E.H. (1991). Organizational Culture and Leadership. San Fransisco : JosseyBass Publisher.

Siagian, S. (2002). Kiat Meningkatkan Produktivitas, Cetakan Pertama. Jakarta : Rineka Cipta.

Simamora, H. (2005). Kinerja Pegawai. Jogjakarta : Sekolah Tinggi llmu Ekonomi YKPN.

Stoner, J.A.F. (1996). Management. New York. Engelwoods Cliffs : Prentice Hall International Inc.

Sudaryana, Y. (2015). Pengaruh Budaya Organisasi, Gaya Kepemimpinan dan pengambilan Keputusan Terhadap Komitmen Organisasi (Studi Kasus Pada PT Sucofindo Persero). Jurnal IImiah IImu Manajemen Inovasi. ISSN 2598-4950.

Sugiyono. (2007). Statistika Untuk Penelitian. Bandung : Alfabeta.

Tika, H.M.P. (2006). Budaya Organisasi dan Peningkatan Kinerja Perusahaan, Cetakan Pertama. Jakarta : PT. Bhumi Aksara.

Nina Ruslinawati and Syarief Gerald Prasetya. Influence of organizational culture, leadership and decision making on employee performance at the Ministry of Defense of the Republic of Indonesia 
The Management Journal of BINANIAGA Vol. 06, No. 01, June 2021

p-ISSN: 2527-4317, e-ISSN: $2580-149 x$

$6^{\text {th }}$ Accreditation Rating: April 04, 2019-April 03, 2024

Wahyuni, Y. (2016). Pengaruh Gaya Kepemimpinan dan Budaya Organisasi Terhadap Kinerja Karyawan PT Sugih Instrumendi Abadi di Padalarang. Universitas Pendidikan Indonesia. Journal of Business Management Education, 1(2).

Yasin, A. (2011). Kepemimpinan dalam Pengembangan Organisasi, Jurnal Lintasan Ekonomi. Malang : Fakultas Ekonomi Universitas Brawijaya.

Nina Ruslinawati and Syarief Gerald Prasetya. Influence of organizational culture, leadership and decision making on employee performance at the Ministry of Defense of the Republic of Indonesia 
The Management Journal of BINANIAGA Vol. 06, No. 01, June 2021

p-ISSN: $2527-4317$, e-ISSN: $2580-149 x$

$6^{\text {th }}$ Accreditation Rating: April 04, 2019 - April 03, 2024

This page intentionally be emptied

Nina Ruslinawati and Syarief Gerald Prasetya. Influence of organizational culture, leadership and decision making on employee performance at the Ministry of Defense of the Republic of

Indonesia 